\title{
Johan Nuorgam: Sámi Squanto and cultural broker
}

\author{
Veli-Pekka Lehtola
}

\begin{abstract}
The role of "Squantos" - different kinds of intermediators, cultural interpreters, or cultural brokers coming from native societies - has been important in encounters between Indigenous peoples and the outside world. The article describes a North Sámi broker, Johan Nuorgam, the founder of the Sámi museum in Inari, Finland. Due to dramatic incidents as a young man, he left his reindeer Sámi life to move to Helsinki, the Finnish capital in the beginning of 1930s. He worked as an informant for Finnish researchers, as a guide in a Finnish outdoor museum, a collector of Sámi artefacts, and an editing assistant in a North Sámi magazine. All this later made Nuorgam a pioneer in Sámi media and politics, as well as in museum management. In this article, I interrogate Nuorgam as a "Squanto".
\end{abstract}

Keywords: Johan Nuorgam, Sámi museum, cultural broker, Squanto, Sámi exhibitions, outdoor museums, collecting Sámi artefacts, Sámi material heritage.

At the borders of different cultures there has always been a need for interpreters and mediators who have crossed these boundaries, both linguistically and culturally. These cultural brokers has emerged from both native and non-native worlds. The latter ones - outsiders coming to familiarize themselves with native people - have always been more visible since they came from the literary societies which could record and distribute their experiences for large audiences.

In Sámi culture, the role of non-native experts and connoisseurs working or visiting in the Sámi area has been studied to some extent, especially the politics of the colonial administration (Karlsson 1995:75-76; Lantto 2000) or the research related to the Sámi often referred to as Lappology (Hansen 1992; Lehtola 2017). A special group of these experts have been called "Sámi friends" in Nordic Sámi research, referring to their efforts to intermediate between the majority and the minority. They could be priests or other officials with working experience in the Sámi area, researchers, or other individuals who were interested and involved in Sámi issues (See e.g. Jernsletten 1997; Rydving 2010.)

It seems, however, that behind many prominent civil servants or researchers who have become known as experts in Sámi issues, 
there is usually a Sámi person to whom they owe gratitude for their (profound) contact with local culture and its knowledge. While the expertise of such civil servants and researchers has attracted attention and praise, the intermediators, cultural interpreters or cultural brokers have often remained nameless figures.

James Clifford has used the term "the Squanto phenomenon" to describe the surprising bilateral nature of cultural encounters. Squanto was a Native American from the Patuxet tribe of the East Coast of North America who, in 1620 in Plymouth, Massachusetts, encountered British Pilgrims who had migrated to the New World. The incomers would have perished in the foreign circumstances without local expertise. However, they received a guide in the form of a Native who spoke good English and helped them manage through the first severe winter. Squanto's quite exceptional background allowed him to understand the difficulties of the incomers and guide them to local traditional knowledge (Clifford 1997:18-19). Squanto is often perceived as an ambiguous figure because he was considered to have expedited the subsequent downfall of his own culture at the same time (Deetz \& Deetz 2000).

In this article, I call attention to Inari Reindeer Sámi Johan Nuorgam, who personified Squanto characteristics and was a cultural interpreter in many ways. The starting point of his life was to continue a traditional lifestyle in the footsteps of his Reindeer Sámi parents in the Iijärvi region in Inari. He lost sight in one eye in an accident in his youth and the treatment took him to Helsinki for many years. Due to his extensive linguistic and cultural knowledge, he became an informant for linguists and professors, as well as a guide and artefact collector for the Sámi exhibition of the National Museum.
These years of learning later made Nuorgam a pioneer in Sámi media and politics, as well as museum management.

The Squanto phenomenon is quite common in different parts of the colonial world. The incomer - let it be a settler, a civil servant, or a researcher - encountered at the interface of cultures an extra-ordinary person who belonged to the Indigenous population and could open doors to his own culture for the outsiders. Squantos have also had a significant role in the relations between the Sami and Nordic societies. They were Sámi catechists or ambulatory teachers, churchwardens, or even Sámi priests. They could be public figures, such as the famous Sámi intellectuals or political pioneers, including the author Johan Turi, the journalist Anders Larsen, or the Sámi politician Elsa Laula-Renberg.

The main reference for Clifford, however, were the men or women in native communities who have been crucial for outsiders to obtain local Indigenous knowledge, but who have usually not been credited in the final report or research findings of the non-native visitor. As Clifford notes, these "informants" are often introduced as casual "locals" whom the incomer seems to have met coincidentally and who may have been made routinely started to share his or her cultural knowledge. On the contrary, they "turn out to have their own 'ethnographic' proclivities and interesting histories of travel", and end up being anomalous or problematic figures even in their own context (Clifford 1997:16-19).

These intermediators or cultural brokers have typically grown out from their own culture at some point, usually by setting out to, or ending up among, the majority population for an extended period. Upon their return, they received the role of intermediator or guide due to their linguistic and cultural 


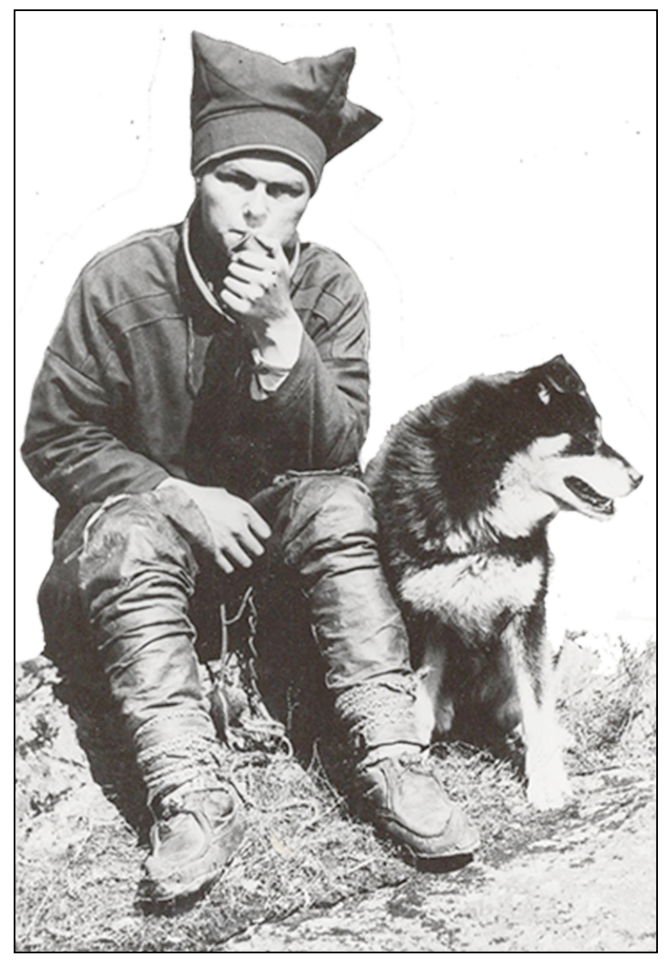

Fig.1. In 1930s, Johan Nuorgam worked as a touristic guide in the Inari hotel. Photographer Aarne Pietinen made an artistic composition. Siida Sámi museum.

skills, but also because they themselves were similarly as interested in other cultures as the incomers. They have wanted to cooperate and have certainly understood their own value in monetary terms, as well as in their increased status in their own community.

In the Finnish Sámi territory, these Squantos are clearly discernible already in the early 20 th century. They were extraordinary personalities in their own communities - respected but also inconsistent figures whose local life histories, like oral tradition in general, are partly forgotten. There is, however, more source information available about those who have worked as background figures for researchers and civil servants. For example, Inari Sámi "Nuoran-Pekka" Saijets, who had made his own "excursions" to the Arctic Sea coast and Pechenga already in his early life, provided invaluable help in ethnologist T. I. Itkonen's field studies and artefact collection (Lehtola 2012:313-316).

Reindeer Sámi Juhani Jomppanen, who had led the "Lapp caravan" to Germany in 1910 and became perhaps the best-known Sámi as "the Lapp gentleman" in Finnish publicity in the 1920s and 1930s, worked as vicar Tuomo Itkonen's assistant, who initiated several projects. Geodesist Karl Nickul's special role as a Sámi friend was closely connected to his friendship with Skolt Sámi Jakk (Jaakko) Sverloff, who had advanced to sergeant major in the Russian army during World War I and emerged as trustee of the Suenjel Skolt village in late 1930s (Lehtola 2005a; about Sverloff see also Hirsti 1972).

Many priests also had Sámi interpreters for their sermons. In addition to linguistic skills, successful mediation between a Finnish clergyman and a Sámi interpreter required knowledge of the culture and customs of both groups. As Nancy L. Hagedorn has noted, in order to properly translate, "interpreters had to have a clear understanding of the hidden, culturally prescribed meanings and values that metaphors conveyed" (Hagedorn 1988:60, 64). When focusing on these meanings and values, it is relevant to speak about cultural interpreters.

In this article, I will use the concept cultural broker to highlight the ways that Nuorgam embodies Clifford's concept of Squanto. Nowadays the term cultural brokering is mostly used to refer to the act of linking different cultural groups to enhance practice and communication in health services, social 
80 issues and refugee processes (Lindquist 2015:9-11; Brar-Josan \& Yohani 2017). In Indigenous studies (Hagedorn 1988; White 2010/1991; Kidwell 1992; Szazs 1994a, b; Michie 2003) the term refers to individuals who cross cultural and social boundaries because of their own will, but obviously also in order to gain something from the mediation of valued resources that he or she does not directly control. The subheadings in my article come from "the Philosophy of life from Iijärvi", which Nuorgam passed on to researchers in the 1930s, and which T. I. Itkonen published in four articles (Itkonen 1934-1935).

\section{"MAN IS NOT BORN WITH LASSO IN HAND" - REINDEER HAND'S PATH TO THE WORLD}

Niillas-Jon Juhán or Oivoš-Juhán or Johan Nuorgam (1910-1978) $)^{1}$ was the son of a Reindeer Sámi from the area of the Iijärvi lake. It was a solid Sámi-speaking country in his childhood. Nuorgam expressed later that he was ten when he saw the first man wearing Finnish clothes, in about the year 1920, "and it was a great wonder for him then". He (told that he) learned Finnish at the age of thirteen, but still in his adult age among Finns he had to "think in Lappish (Sámi) before saying anything” (Uusi Suomi September 21, 1934).

This seems to refer to the lack of multicultural influences, which is characteristic for many other native and non-native brokers: these brokers were often born in the borders between cultures "with a foot in each culture", for instance, as children of multiethnic families (Szasz 1994a:8-9; Hämäläinen \& Truett 2011). A closer look, however, reveals that even if the early Finnish contacts were missing, the North Sámi Nuorgam family was living in the Inari Sámi area, where the grandfather of Johan had moved from Deatnu Valley as a reindeer herder. The region was also transited by reindeer travelers - both Sámi and Finns - who journeyed the traditional Sámi "highway" from Inari to the Arctic Ocean or the Norwegian Varangerfjord, where traffic connections were mainly directed to at the beginning of the twentieth century.

Many stories, which Nuorgam later told to researchers and which have later been published in the Sámi language (Nuorgam 1982), originated from childhood and the life of a reindeer hand. These included traditional tales of Stuorr-Ántte-Anna's magical skills, reindeer Sámi customs, and different mythical beings. Nuorgam could also talk extensively about everyday philosophy of life from proverbs to natural knowledge. The young man worked as a reindeer hand for two rich Reindeer Sámi, "Leaská-Káre” or Karen Panne, a widow reindeer herder, and Piera Siri who herded his reindeer on the northeast side of Lake Inari near the Norwegian border. The reindeer hand was assigned the task of preventing Norwegian reindeer from mixing with Siri's reindeer. This also concerned the last wild reindeer in the area.

The direction of Nuorgam's life changed when he was about twenty: his eye was badly injured in a reindeer accident. Finnish professor Frans Äimä, who was conducting linguistic field work in the Inari area and who had noticed Nuorgam's evident aptitude in language as well as traditions, invited him to Helsinki to receive treatment from an eye surgeon. At the same time, he himself acquired a language master whom he could meet daily. The treatment for the eye was not successful, and consequently Nuorgam could not return to reindeer work. Instead, he remained in the capital for a total of five years (Ravila 1934, 7-8; Itkonen 1960, 2). 


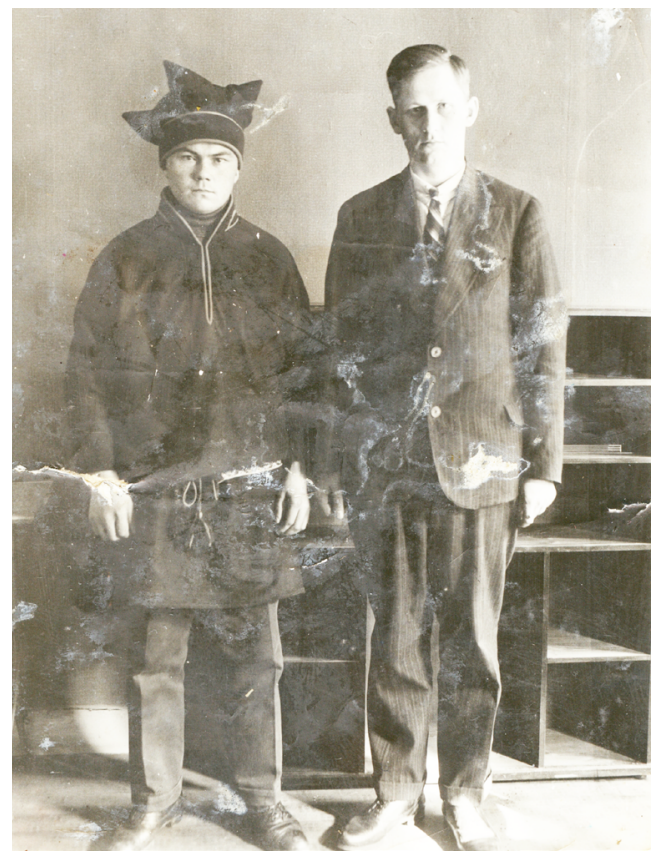

Fig. 2. At the beginning of 1930, Johan Nuorgam assisted many Finnish researchers. Linguist Paavo Ravila collected a lot of linguistic and folklore material from him. National Museum of Finland.

Apart from Äimä, other researchers were excited about the young man's extensive knowledge of grammar and his rich vocabulary, but he also had endless knowledge of the Sámi way of life and beliefs. In 1932, Nuorgam participated in fieldwork for the first time when he toured with linguist Paavo Ravila to collect language samples in the Inari region and especially in Iijärvi, where they stayed in Nuorgam's home.

At T. I. Itkonen's request, the men also delivered artefacts to the National Museum. "Puorre Tuoktär" ("Good Doktor"), or Itkonen, received humoristic descriptions in letters written in slightly broken Finnish: "Ravila said that it would have been otherwise good. But as lice have taken to communism, when there was a big red louse on his neck each morning, and bright red it was" (J. Nuorgam to T. I. Itkonen 29.8.1932. TIIA. KA). After Ravila left, Nuorgam stayed in the north to work for the reindeer herding cooperative. He continued his collecting work and delivered a large number of artefacts to Itkonen, some of which he bought with his own money in order to receive potential remunerations later. Messages came from the field in all kinds of weather: "Now that there was frost and ink had frozen, I wrote with a copying pencil at first while Martti Saijets was warming the ink. Excuse me for doing so" (J. Nuorgam to T. I. Itkonen 8.9., 10.11. and 29.12.1932. TIIA. KA; Ravila 1934,8$){ }^{2}$

\section{"People Will RUN OUT OF NetS Before FISH RUN SHORT IN THE LAKE" - OPEN- AIR MUSEUM GUIDE AND PROFESSORS' ASSISTANT}

The National Museum of Finland had founded an open-air museum on an island called Seurasaari near Helsinki. The initiator of the Seurasaari attraction, A. O. Heikel had been inspired by the work of Arthur Hazelius and the Skansen open-air museum in Stockholm (Niiranen 1987:57). Heikel wanted to present Finnish folk culture, but in the 1910s "a Lapp section" was also built there. The first acquisition was "a Lapp tent - in a special boardconstructed shelter” brought from Menesjärvi in Inari. According to the museum's guidebook "A civilised person finds it incomprehensible how man can live throughout the year in such a flimsy dwelling" (Guidebook for the outdoor museum 1913. KM). "A reindeer and a young Sámi boy from Nuorgam and skilled with his lasso" were also brought to the open-air museum in 1914 (Niiranen 1987:60). A later 
annual report specified that the reindeer "was brought alive from Inari in winter 1914, but was not placed in the Lapp tent until April 1915, after university preparator Mäntynen had stuffed it with plaster and iron" (Annual report 1916. KM.).

In 1932, the National Museum of Finland noted that Mountain Sámi (fjällappen) Johan Nuorgam had acquired three storage structures for the open-air museum (VIII Friluftsmuseet på Fölisön. Helsingfors 1937. KM). The artefacts brought by Nuorgam were an indication of a new phase where intendent T. I. Itkonen purposefully began to develop the Sámi section. He wanted Nuorgam to work in the Lapp section of the open-air museum as a janitor and presenter.

In February 1933, Itkonen wrote to the State ArchaeologicalCommission that the Seurasaari open-air museum had expanded into a whole "village" with a total of 80 buildings in varying sizes and sorts. It nevertheless had only one janitor, whose tasks included overseeing the museum's property and orderliness, making minor reparations to the buildings, arranging and participating in cleaning as well as shovelling snow in winter, like shovelling snow off the roofs of buildings and the long roads. The previous janitor "fell irremediably ill from excessive strain and worry". To arrange funding for hiring a caretaker in addition to a janitor, Itkonen argued,

When the recently founded Society for the Promotion of Sámi Culture has taken action to bring some native Lapp to Helsinki for literary work carried out here in the Lapp language, such as writing an ABCbook and reading book, editing a Lapp newspaper and translating Lapland-related decrees to the Lapp language, the board of the Society for the Promotion of Sámi Culture and the warden of the Open-Air Museum have agreed that the Lapp in question could work in Helsinki also as a caretaker. We happen to be informed about a Lapp youth Johan Nuorgam from Inari, who is suited for both purposes and who worked here already last year with good success as language master for Lapland researchers and last summer also as a Lapp hut dweller and presenter of Lappish life for museum visitors in the Lapland section founded in the open-air museum. As a diligent, regular and otherwise stout man and skilled woodworker, he could carry out caretaker tasks in the Open-Air Museum for the time being and appear daily as "an attraction" in the Lapland section at appointed hours.

Itkonen suggested that the State Archaeological Commission could apply for 12,000 marks from the available funds of the Finnish Government for hiring a caretaker. He could live for free in the empty kitchen on the upper floor of the Open-Air Museum office and janitor house (T. I. Itkonen's letter to the State Archaeological Commission 31.1.1933. KM). The museum published a press bulletin already the same spring:

New attraction in the Seurasaari Open-Air Museum For a long time there have been two Lapp buildings in the Open-Air Museum, near the Seurasaari bridge, e.g. a log hut brought from Suonikylä in Pechenga and a bear cache put together on top of a long pole. Reindeer Lapp buildings have now been erected beside them "on the fjell", including a movable cloth hut used by a nomad family, meat drying rack ("suödnjir", written in mixed orthography), storage platform ("luövvi") and canopy covered with birch bark ("luökti”).

Mountain Lapp Juhani Nuorgam from Inari lives there and presents Lapland's life, throws lasso, softens shoe grass, explains food management and vehicles to the audience - the display includes various types of sledges and skis - even sings yoiks. The Lapland section opens on Sunday, May 12th at 12 hours and 
is then on display also on weekdays in June and July between 12 and 18. (Undated advertisement text, probably from spring 1933 . KM).

The work was not particularly ideal, for Albert Hämäläinen wrote, evidently already after the first summer, that despite the demanding job the janitor was in a greatly unfavourable position next to other janitors of the Finnish Heritage Agency in respect of fringe benefits. The dwelling was quite small, only a diminutive kitchen and room, and it lacked conveniences, such as central heating or toilet (Undated advertisement text, probably from spring 1933. KM.).

The work as a guide in Seurasaari lasted for two summers. Seeing the operation of the open-air museum probably kindled a spark in Nuorgam to start planning a similar solution to Inari a few decades later. When the section was threatened the following winter with closing down, and Nuorgam with unemployment (J. Nuorgam to T. I. Itkonen 20.5.1933 and 25.6.1934. TIIA. KA), researchers arranged other work at the University of Helsinki. The Uusi Suomi newspaper in 1934 described: “The university department of phonetics is in a small, dilapidated-looking stone building on the corner of the Hallituskatu and Fabianinkatu streets. A young Lapp Johan Nuorgam now works there as a janitor and at the same time as the Lapp language master, and his presence and skill are a great benefit to Lapp language students and researchers" (Uusi Suomi September 21,1934.).

The new orthography or spelling style of so-called Lapin Sivistysseura (Society for the Promotion of Lapp Culture) that Ravila was developing was probably influenced by Nuorgam. It was introduced in 1934 and it was based on the dialect Nuorgam represented. Nuorgam described in publicity that it was based on Finnish orthography and that it substituted Finnish words in a Lappish form for missing Lapp language words. He supported the new orthography, rather than using the Norwegian spelling, because it made it easier for the Sámi to read their own language (Uusi Suomi September 21, 1934).

Nuorgam was a candidate for the post of chief editor in the Sabmelaš newspaper, which was founded in 1934, but then Finnish linguists decided to take on that task themselves. The deciding factor was perhaps Nuor $\neg$ gam's inexperience in literary expression, but there may also have been a more general lack of confidence in the ability of an uneducated "Lapp" to act reliably. This is also suggested by the fact that Nuorgam did not even belong to the board of the Society for the Promotion of Sámi Culture, which worked for the development of his own kin and culture.

Instead, Nuorgam could work as an assistant for the Society for the Promotion of Sámi Culture and Sabmelaš as much as he liked. When a university linguist or professor faced a problem with North Sámi language, he only had to sprint downstairs to ask for the answer from the janitor. Nuorgam translated texts written by Finns, proofread for linguists and also wrote texts himself. When Ravila and Itkonen checked the new orthography of Tuomo Itkonen's ABC-book in the Sámi language, Nuorgam acted as a native language master (Itkonen 1960).

Paavo Ravila and T. I. Itkonen interviewed substantial collections of traditional, as well as, linguistic material from Nuorgam. In 1934, Ravila published a collection of stories in German based on interviews of Nuorgam. Ravila’s work had Sámi language transcription, which made it somewhat difficult for the Sámi themselves to read. Nuorgam was not mentioned as an editor of the book alongside 
Ravila, but in the foreword he received high praise as a storyteller and guide (Ravila 1934). Also, Itkonen published many sets of folklore collected from Nuorgam in the Kalevala Society yearbooks (1934-39). At the end of the collections, he credited Nuorgam as the storyteller (Itkonen 1934-37, Itkonen 1938, 1939).

The tradition that Nuorgam mediated to Itkonen remained alive in researchers' texts. When Itkonen published his magnum opus Finnish Lapps I-II in 1948, he also included the material he had collected from Nuorgam. It no longer constituted a separate entity; Itkonen included it as general Northern Inari Mountain Lapp tradition (Itkonen 1948 I-II). The oral history of a single storyteller then merged into a researcher's extensive composition of the general characteristics of Sámi culture. In 1982, a Sámi publishing house, Jårgaleaddji, reprinted Nuorgam's stories in a booklet under his own name. Paavo Ravila was mentioned as a "recorder" (Nuorgam 1982).

\section{"YOU WON'T CATCH ANY FISH IF YOU DON'T GET YOUR FEET WET" - ALWAYS ON THE MOVE}

Nuorgam probably considered his stay in Helsinki as a learning experience which brought him knowledge he could later benefit from. However, he did not enjoy his stay very much in the south where life often felt "strange and tedious". This was the case especially in autumn when the Sámi man missed the changing seasons of the north. Nuorgam made observations of living in a city: "In Lapland you may walk continuously through a day and night, and then you can still work for another day. But here you get tired quite quickly. A short walk downtown is already tiring. The air is so heavy and oppressive.
A man cannot last long here" (Uusi Suomi September 21, 1934).

In 1935, Nuorgam received a scholarship from the Society for the Promotion of Sámi Culture and the Finno-Ugrian Society for a trip to Utsjoki. Now he had his own notebook where he recorded traditional knowledge. Regarding the collecting of artefacts, hearsay has it that he had a dream of acquiring a shaman's drum, but the rumour proved to be unfounded. The collected objects, consisting of many rarities, reflected Nuorgam's desire to demonstrate his own expertise to the Lappologists (T. I. Itkonen to I. Itkonen 27.9.1935. TIIA. KA.) Nuorgam's collections from the 1930s were repatriated to the Siida Sámi museum by the National Museum of Finland in 2018 to be displayed in the exhibition of Johan Nuorgam.

History was made in 1936, when Nuorgam founded the Syysjärvi youth club in his home region. It was the first Sámi association in Finland, although it originated as a branch of the Society for the Promotion of Sámi Culture by means of a 1,450-mark grant. The society had assigned him to clarify "the wishes of Lapps concerning their own educational pursuits in Northern Inari and Utsjoki” (Katsaus 1937, 9-10). About thirty people participated in the founding meeting, which is the same number of people as in the first meeting of the Society for the Promotion of Sámi Culture in 1932 in Helsinki. The meeting was opened by Sammeli Valle, who emphasised the importance of preserving Sámi culture. Kaisa Kangasniemi read thoughts from a book about the tasks of youth clubs in general.

The goal of the new club was defined as educating the Sámi people in a way that the national feeling inherited from ancestors (maddar-aččiin arbijuvvum albmuglašvuottamek) could be preserved and developed by the new society. Nuorgam himself was 
elected chairman and Hannu Musta became the vice chairman. The board also consisted of reindeer herders Uula Högman and Sammeli Valle, as well as freeholder Matti Sarre. The secretary was Maria Mattus, who was the first, and until 1948, the only woman in the whole administration of the Society for the Promotion of Sámi Culture (Minutes of Syysjärvi youth club founding meeting 7.6.1936. LSS board minutes Oct 2, 1936. LSSA, KA; "Lapin Sivistysseuran hallituksen jäsenet" see Bálggis - Polku 1984, 113-114; Sabmelaš 3/1936, 3).

In joint meetings with the Society for the Promotion of Sámi Culture, the youth club considered collecting and recording traditional and oral knowledge as its foremost task. While the decency and humility of ancestors was emphasised, educational work was aimed at opposing harmful customs, such as "drunkenness and overdressing". Activity in the youth club seems to have been lively the first summer. It arranged lecture events in the Syysjärvi region, where the speakers were Sammeli Valle and Matti Mattus, in addition to Johan Nuorgam. In an event arranged in the Inari parish village at Midsummer, the lecturers were the vicar Tuomo Itkonen and Johan Nuorgam, whose subjects were "Youth club requirements" and "How can we work for the good of our people" (Syysjärvi youth club annual report 1936. LSS board minutes Oct 2, 1936. LSSA, KA).

The club announced in its yearbook that it had published its own club paper named Sabmi, which all club members could write in. Despite the vigorous beginning, the activity of the local association seems to have dwindled right away in the first year. The reason was probably the depletion of Nuorgam's grant, after which he returned to Helsinki. The locals were not active in maintaining the operation of the association (Syysjärvi youth club annual report 1936. LSS board minutes Oct 2, 1936. LSSA, KA.).

There is little information about developments in Nuorgam's life in the late 1930s and during wartime. He is known to have worked as a tourist guide at a hotel in Inari, where the press photographer Aarne Pietinen took a famous photograph of him. Due to the eye injury in his early life, Nuorgam belonged to the home reserve of the Finnish army and was not called to duty until the last days of the Winter War. In the Continuation War against the Soviet Union, he served at the Pechenga front in the north as a stretcher bearer in Unit Pennanen's medical corps.

After being wounded in the front lines in 1943, Nuorgam convalesced in the Oulunsuu war hospital in Oulu, which later became his home town for many years. Nuorgam was trained to be an air raid protection man, and he served as such in Pechenga at first, and also later during the Lapland War in Oulu and Kemi. Evidently while holding these duties, he became acquainted with the Finnish woman, Laura Soronen, who worked in the women's auxiliary services at the home front in Oulu. At Christmas 1944, or during the Lapland War, they got married. Nuorgam found work after the war as a janitor at the Oulunsuu school, where the war hospital had operated. ${ }^{3}$

\section{"NOT BY FORCE BUT BY CUNNING" - Journalist, POLITICIAN, EXeCUTIVE MANAGER}

Nuorgam was a "disciple" of the Society for the Promotion of Sámi Culture, who in his post-war activities, carried out the lessons he learned in Helsinki. He began to use his skills as a Sámi-speaking journalist and from experience from his Finnish club activities. 
The Samii Litto association, founded by Sámi in 1945, got an active member in Nuorgam, who worked as an organiser in the association together with Antti Outakoski's family during his years in Oulu. They were involved in making Sámi communications history when the Sámi radio started its operation in Oulu in 1947 (Lehtola 1997; Lehtola 2012).

Samii Litto's first chairman was Nilla Outakoski, who represented a radical line towards Finns and the Society for the Promotion of Sámi Culture. Nuorgam represented a conciliatory approach, and he wanted to make practical work for the Sámi people rather than act in public as a politician. In 1949, the association founded an executive manager post, and the location was Inari. Outakoski did not apply for the executive manager post but focused on his theological studies. The elected executive manager, Nuorgam, moved with his family in January 1950 to Inari, where Samii Litto's headquarters - a small barrack building - also became the family's home for years. The living room functioned as a meeting place of the association and entertaining venue for numerous guests (Applications to executive manager post, Board minutes Aug 15, 1950. SLA).

The following years were the most fruitful time of Samii Litto. Samii Litto acquired a Rapid press and proofing machine in 1949 from Oulu. It was more economical to own a print shop than have the material printed in the south. It also enabled the Society for the Promotion of Sámi Culture to decide to move the editing office of the Sabmelaš newspaper to Inari and print it together with Samii Litto. Nuorgam became the chief editor (Minutes of board meeting Nov 27, 1950. Board minutes 1947-1962. SLA).

After moving to the Sámi territory and into Nuorgam's hands, Sabmelaš became livelier and fresher. As a radio journalist, Nuorgam had acquired good experience from journalist work and could use his relations to get a lot of people to contribute to the paper. Nuorgam also edited the weekly Finnish-Sámi Tunturisanomat newspaper, which covered Sámi and more generally North Lapland's affairs; the chief editor was Pekka Lukkari.

Samii Litto arranged reindeer races, entertainment, and educational events, which attracted hundreds of people. For example, lectures were given to more than 500 listeners in Karigasniemi, Inari and Nuorgam in 1951. Subjects ranged from the Sámi pioneer Isak Saba to sports from earlier times. The next year, a total of nine lecture events were arranged with several speakers. There was a total of almost a thousand listeners. ${ }^{4}$ The events were popular, partly because in Nuorgam's time, Samii Litto did not exclude the local Finnish population - the events were arranged in cooperation. Samii Litto also developed regular cinema activity.

The sports activities of the association expanded in the early 1950s, so much so that the local sections had to be founded in different villages. There were four of them in the Utsjoki parish in 1952, five in Inari and one in Vuotso. Sports ranged from athletics to Sámi skiing competitions. The association arranged four competitions in a year: summer and winter competitions in Karigasniemi and a summer competition as well as the Feast of the Annunciation competition in Inari (Annual reports 1950-1953. SLA).

The operation of Samii Litto fell apart in 1952-1953 because of personal disputes. The situation had become heated over the folk high school issue, and the result was that while Jomppanen and Nuorgam were busying themselves with the school construction, the "Nilla branch" of the association seized power 


\section{Johan NuORgam: SÁmi SQUANTO AND CULTURAL BROKER}

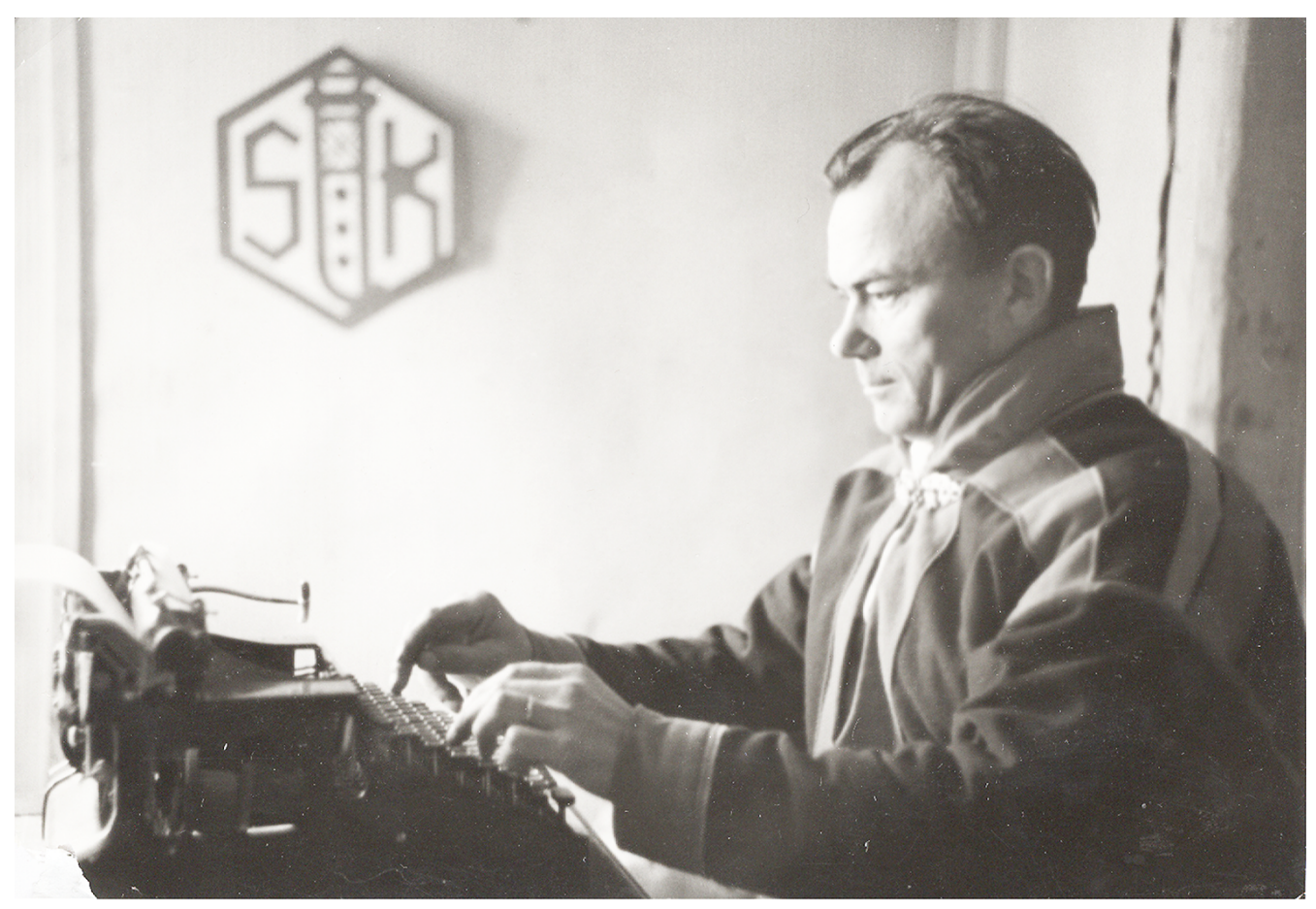

Fig. 3. As the executive manager of Samii Litto, Nuorgam even envisioned a trade mark for Sámi duodji or handicraft ("Sami kalvu"), which is shown in the photograph by Matti Poutvaara at the beginning of 1950s. Tourist Union of Finland.

in the summer of 1953. According to later reasoning, the "rebels" were concerned about the financial status of the association caused by Nuorgam's (and Jomppanen's) inefficient actions (J. Nuorgam's statement 20 April 1950, see also other Minutes 1946-1953. SLA; Lapin Kansa 26 July 1970; Lapin Kansa 5 January 1971).

After various stages, Jomppanen, who was already an experienced politician, brought the rebels under control. They were dismissed from the board and the association. Jomppanen also made more purges in the association at the same time, for the summer meeting had given good means for making them. Membership fee forms were handed out only to "reliable persons" from then on. All others were wiped from the lists - they had not paid membership fees (which they were not reminded of either) (Minutes of annual meeting Nov 2, 1953). ${ }^{5}$

Samii Litto began to operate on a narrower basis during the 1950s, and it was even referred to as "a two-man organisation". Only Johan Nuorgam from the old active members continued beside Jomppanen. Samii Litto, which regarded itself as the representative of all Sámi in Finland in the 1960s, met with the same fate as the Society for the Promotion of Sámi Culture in the 1940s, when young Sámi challenged the association they considered 
corrupt and toothless (J. Nuorgam's clipping collection from 1969-1971, when the affairs of Samii Litto were heatedly disputed. Clippings. SLA.)

Thinking about the role of Nuorgam as a cultural broker or a middleman, an interesting contradiction in the Sámi ethnopolitical movement occurred already from the start. In his political view, Nuorgam represented a "middle ground" with a sympathetic or conciliatory attitude towards the Finns. Contrary to this, the radical wing of the Samii Litto movement, represented by Outakoski, emphasized the antithetical position between the Sámi and the Finns, arguing ethnic differences in more essentialized, sometimes even racial, terms (See Lehtola 2005b).

The actions of Jomppanen in Samii Litto overcame the inner opposition for a while, but the distinction between the reconciling and radical factions in the Sámi movement appeared another time at the end of 1960s, when the radical Sámi movement began to challenge not only the outsider Sámi friends, but also the "older generation" attitudes.

Young "radicals" made several attempts to gain a foothold in Samii Litto and even began to establish a new national Sámi organisation. Balancing between the fronts, Nuorgam took a historic initiative in 1971 to found a Sámi democratic representative body, a parliament, in Finland (Lapin Kansa 1971). The stateappointed Sámi committee was, in a sense, an attempt at making a compromise in this dispute. In 1972, the government founded a Sámi delegation with 21 members, the first Sámi parliament in the whole world. The older generation and younger activists represented opposing views in many respects in the delegation. Nuorgam was a member of the Sámi parliament in 1973-1975 (Lehtola 2005a).

\section{“TIME IS THE BEST TEACHER" - Establishing The Sámi Museum}

Directly after returning to Inari, Nuorgam apparently began to plan utilising his own museum experience for the benefit of the Sámi community and the bolstering of Sámi cultural heritage. In 1959-1963, Samii Litto and Nuorgam established the first Sámi museum in all of Sápmi and from the very beginning, it was planned and administered by the Sámi people themselves. As is often suggested, the museum was a colonial structure that was adopted by the Sámi themselves. In addition, it has been suggested that the Sámi museum also adopted the outsiders' models for representing native cultures, thus repeating the representations of the majority (Olsen 2000; Potinkara 2015).

There is also another possible interpretation. The early Sámi museum can be considered to actively extend the ideas of cultural brokerage, to be an institutionalized Squanto phenomenon. Just as an individual broker, the institution was equally allied to both sides, reading "both maps" of the two cultures and changing roles depending on circumstances and necessities. It could be an insider and an outsider simultaneously in two worlds, knowing how the "other side" thinks and behaves and being able to respond accordingly (Hagedorn 1988:61; Szazs 1994a:6).

The Sámi museum constructed by Nuorgam reflected his own experiences and skills from both sides. In a post-war situation, he understood that some adaptation to the new environment was a necessity for his own people. The means of securing the support and interest of the majority was to visualize and institutionalize Sámi heritage, which seemed to be disappearing. He started to bring together Sámi knowledge and heritage with the "European" museum institution, especially it's 
special trait of the outdoor museum, leading from Skansen in Stockholm to Seurasaari in Helsinki.

The reconstruction caused by the Lapland War gave the impulse for founding a museum. Along with new standard houses, also many Sámi adopted Finnish values, which lead to deprecation of their own culture. They started to reject and deface "old fashioned" Sámi things. Even artefacts that were in good condition had to make way for plastic and porcelain, and were demoted to secondary purposes, such as milking pails in cowsheds, or they were thrown away completely. They could also end up as "children's playthings or other such places where they are in danger of getting lost altogether", as Nuorgam himself noted (Nuorgam 1984).

He started to collect artefacts and he advised people to collect and donate museum pieces in Sabmelaš. The idea of establishing a museum probably derives from the Seurasaari Open-air Museum in Helsinki, as he had worked there in the 1930s. Thus, the open-air museum in Inari was closely related to Skansen in Stockholm, which had inspired the establishment of a similar institution in Seurasaari (Niiranen 1987:57).

In the 1950s, the idea of founding a museum was in the air in several places, Saimi Hakasalo, teacher at the Koppelo school, had collected artefacts in Ivalo, where she planned to establish a local museum with support from local Finnish freeholders. The Ivalon Pirtti building of the Society for the Promotion of Sámi Culture also collected artefacts, especially of Skolt Sámi origin. In March 1959, the board of Samii Litto took a unanimous decision in favour of the project. Nuorgam was the museum's originator and practical implementer, while the well-connected Erkki Jomppanen had the skills to get support for it.
By the end of the year, the association had 89 received over a hundred museum artefacts, three huts, four ordinary granaries, and two bear caches. Mapping old dwelling and habitation places started under the direction of forest technician Lauri Arrela. Nuorgam himself directed the collection of oral history.

The project gained new momentum in 1960, when the chief of the botanical research institute at the University of Turku and director of the Kevo Subarctic Research Institute, professor Paavo Kallio, became inspired by the project. He arranged a collection together with the student unions of his university, and it produced 851 donated artefacts "and some of them were quite rare, even ones that have been assumed lost from this region long ago". Students made valuable interviews and building measurements (Sainio 1963:120123).

Financing the actual museum building was a problem. Kallio's role is significant in that the association could acquire a seven-hectare lot on a hill on the north side of Juutuanjoki river from the National Board of Health. In 1961, the Ministry of Education granted half a million marks for founding an open-air museum in Inari. The project received many donations, some quite large. The grants made it possible to dismantle the so-called Tirro village, an entity of Inari Sámi log houses from 18th and 19th centuries, and move it to the museum area.

Nuorgam seems to have wanted to shatter the prevailing representation of the "homogeneous" Sámi culture by including all Finnish Sámi groups. The differences were highlighted through the introduction of the major dwelling types in the Inari area with their accompanying buildings and artefacts. The fisherman village represented traditional Inari Sámi culture, the nomad village depicted 
Western Inari Reindeer Sámi culture and the Skolt village depicted the eastern habitation type. The Tirro village in the heart of the museum already represented new log building habitation or farming culture. The two-hectare "hunting area" presented trapping equipment and techniques.

Following Hazelius' line of thought, Nuorgam considered that the environment of the museum should also correspond with the culture being displayed. Therefore, the artefacts should not be placed in glass cabinets but outside in the terrain. Nuorgam designed his museum in the shape of a lasso with a route almost a kilometre long. The start of the round from log houses, which presented such things as musical instruments used by catechists or ambulatory teachers, reflected Nuorgam's wish to renew the image of Sámi culture, which was not mere hut habitation.

However, war also constituted a boundary for Nuorgam's museum thinking, which derived from the ideals of the Finnish Lapland researchers he knew. Retreating German troops had constructed lines of defence with dugouts and trenches on the hill during the Lapland War. They were located right at the beginning of the outdoor museum circuit and depicted the most essential cause for the radical change in old Sámi culture. Nuorgam, however, never commissioned repairs to this clearly museum item, which would have given the museum round a startling opening by contrasting the traditional Sámi and the "destructive modern world". He rather followed the ideal of his Finnish Lappologist friends that only the old Sámi culture was valuable and "genuine".

The Sámi museum in Inari focused on everyday material culture of the Sámi before the World War II. The exhibition can be seen to repeat the "ethnographic present" of the outsider museums, but it also lacked some basic elements of majority depictions. Items representing the old mythology, such as sieidis or shaman drums, were not displayed. It is possible that Nuorgam considered them to be too exotic for the museum for the Sámi themselves, but the more probable explanation is that he did not want to give any kind of reason for the Christian or Laestadian Sámi to be offended by the display. Samii Litto had faced some episodes of this kind in earlier years. Thus, the sensitive issues concerning their own views of the Sámi seem to be considered in this respect.

The museum was opened to the public in June 1963. It became a large-scale cultural broker institution between the Sámi and others. There were about 2,500 visitors in the first summer, but the number increased rapidly. It exceeded 14,000 visitors in 1966, and was already over 21,000 at the beginning of the 1970s. The Sámi Museum became an outstanding and extensive sight that attracted large numbers of tourists from home and abroad. Cooperation between the museum and the University of Turku proved important and enduring, as it lasted for decades. Students continued collecting both artefacts and oral history during their summer camps (Lehtola 2003:470-472).

\section{Conclusion}

When the Finnish-American junior researcher, Pertti J. Pelto, was planning his doctoral thesis at the University of California in Berkeley in the middle of the 1950s, he was thinking about a subject connected to "Lapps" or the Skolt Sámi. His acquaintances in Helsinki recommend to him that he stop in Inari to get real local traditional knowledge from a certain Johan Nuorgam. At his place, Pelto received proper instructions on "how to conduct himself, what 


\section{JOHAN NUORGAM: SÁmI SQUANTO AND CULTURAL BROKER}

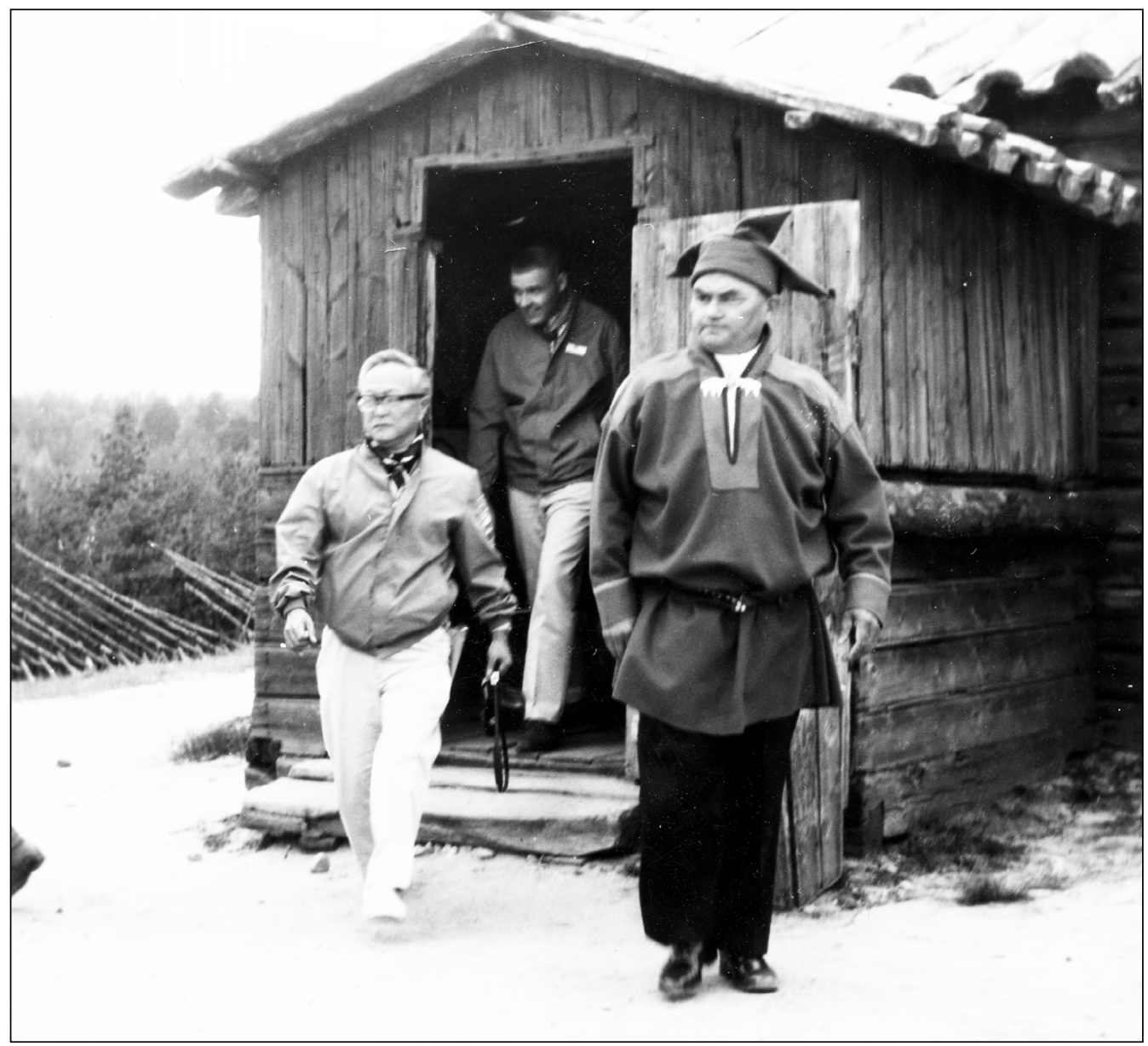

Fig. 4. In addition to royal visitors, the ambassador of Japan, Toshio Yamanaka visited museum at the 1970 s. Photo: Teuvo Lehtola.

you need when you go to the field". Nuorgam told him about the modern life of the Skolts, instructed the researcher in the use of forest skis, and advised him to choose proper boots and switch his coat to "a Lapp coat" of fur (Pertti J. Pelto's interview Aug 22, 2016).

The event was not unique, but rather a rule in Nuorgam's life. He worked as a guide and gateway to Sámi culture for outsiders his whole life. Since the 1960s, he helped linguists on their way to the Sápmi, and tourists, as well as visitors to the Sámi museum. Journalists knew where to go to when they needed information about Sámi affairs. Johan Nuorgam was the standard interviewee and photographic model for southern journalists, especially after the museum was founded.

Like cultural brokers generally, Nuorgam 
was shuttling between two cultures, or as Szazs defines it:

Moving across these frontiers demanded extraordinary skill. Intermediaries became repositories of two or more cultures; they changed roles at will, in accordance with circumstances. Out of necessity, their lives reflected a complexity unknown to those living within the confines of a single culture. They knew how the 'other side' thought and behaved, and they responded accordingly. (Szazs 1994a:6).

What was Johan Nuorgam gaining, then, from his intermediation, as Szazs (1994a:8-9) suggests? There is no knowledge of if Nuorgam received any material rewards; rather, it seems that the publishing activities incurred financial loss for him, as well as most of the guidance he gave to researchers or Finnish politicians.

More important for him was the respect and affection Nuorgam got from the Sámi and Finns, as well as international guests, like Pelto, or the Sámi from other countries. This kind of appreciation must have brought personal satisfaction to Nuorgam, who in a way had lost his everyday status in the reindeer Sámi society. The broker role also offered a sense of power to a certain degree, but it seems that Nuorgam ceded at least a part of this role to Jomppanen, who was using his authority in local and national politics.

There have been a great variety of cultural brokers among Indigenous peoples. Some were inter-preters, or linguistic brokers. Others served as traders, and thus as economic brokers. Some acted as spiritual intermediaries, others were educational or political brokers. Nuorgam seems to cross all these boundaries in his multifaceted activities. Szazs describes the lives of brokers as juggling the ways of different so $\neg$ cieties, and often with apparent ease. They were acting at frontiers "where cultural borders rub together", but "these borders have become pathways that link peoples rather than barriers that separate them" (Szazs 1994a:3).

Juggling between cultures also resulted in difficulties for the brokers. According to Szazs (1994b: 294-297), their role demanded trustworthiness which "locked them into positions that offered rewards but often countered those rewards by immeasurable difficulties". This was due to both their own society and the outsider demands. This resulted in a kind of juggling act: "if the juggler did not suspend the apples and oranges in the air, one of the two sides or the juggler suffered the consequences". Szazs refers to the notion that the connection of brokers to their own society was not without difficulties: they were not the greatest heroes among their own people (Szasz 1994a:15).

Nuorgam's guest books indicate that his relations to different Sámi groups were lively. Many later influential persons found inspiration or additional energy for their Sámi work at Nuorgam's. ${ }^{6} \mathrm{He}$ was not, however, unanimously acknowledged or wellreputed among the Sámi people in Finland. The reason for this was also his middleman attitude, which annoyed the more radical Sámi policymakers. Nuorgam and Jomppanen were clearly perceived as representing a corrupt establishment who had to retreat. The role of Nuorgam as a forerunner of promoting his own culture and rights were blurred for decades.

Nuorgam's greatest achievement was the Sámi Museum, which can be considered a consistent and composite result of the events in his life, especially his introduction to museum management in the National Museum's Seurasaari. Apart from the roles of informant, journalist, and politician, he learned during his trips to the south how his own cultural heritage can be preserved and 
developed through the museum institution. This lesson was vitally important in the postwar years, when also the Sámi were overcome with "the craze of modernisation" and the old culture became despised.

At the same time, Nuorgam's idea of a Sámi Museum constituted an interesting culturehistorical continuum in the development of the European museum institution. The Sámi Museum developed by Nuorgam (as well as Siida, which has expanded its operation) has proved that it could be made into a distinctive mediator of cultures, an institutional "Squanto phenomenon", which relayed its own story to the Sámi themselves, and another story to visitors from outside.

\section{Notes}

1. The exact date of birth was March 10, 1910. His father Jouni (Jon Nilsson) Nuorgam had moved there from the Finnish Deatnu Valley where also Johan's brother later "returned". In Sámi naming forms, Niillas-Jon Juhan refers to the family background or three generation continuum to Juhán, son of Niillas’s son Jo(un). Oivoš-Juhán, on the other hand, is a geographical reference to his native home, Kitinlompolo in Iijärvi inInari.

2. Nuorgam delivered e.g. a rarity, a snow scraper made of horn, an artefact resembling a Lapp knife, used for shaking snow from the fur coat and feet when entering a hut. T. I. Itkonen to I. Itkonen May 27, 1933. TIIA. KA

3. Nuorgam's wife Laura was the daughter of agent K. A. Soronen from Haukipudas. Laura's son Juha (born 1940).

4. The lecturers were Nuorgam, J. E. Jomppanen, Pekka Lukkari, reindeer husbandry adviser Vilho Kiuru, tecnician M. Räsänen, teacher Eino Lukkari and catechist Jooseppi Lukkari. The lectures were delivered in Sámi, except for those of the Finnish speakers.
5. In member lists between 1953-1954, as well as the end of the 1950s, hundreds of members have "resigned" due to "non-payment" of membership fees". Minutes 1946-1960, SLA.

6. E.g. relative girl Helvi Nuorgam-Poutasuo often "escaped" from the Ivalo dormitory to her uncle in Inari. Inspired by social influencing, she became one of the most pivotal agents in developing the official status of the Sámi language in Finland and the Nordic countries in the 1970s. Lapin Kansa 6 August 1978.

\section{REFERENCES}

\section{Archival sources}

Kansallisarkisto (KA, National Archive of Finland) Lapin Sivistysseuran arkisto (LSSA, The Archive of Society for the Promotion of Lapp Culture) Minutes of Syysjärvi youth club meetings in 1936

T. I. Itkosen arkisto (TIIA, The Archive of T. I. Itkonen)

Correspondence between T. I. Itkonen and J. Nuorgam and 1933-35

Kansallismuseon arkisto (KM, Archive of the National Museum of Finland)

Ulkomuseon opaskirja (Guidebook for the open-air museum) 1913

Annual report 1916

VIII Friluftsmuseet på Fölisön. Helsingfors 1937

T. I. Itkonen's letter to the State Archaeological Commission 1933

Undated advertisement text, probably from spring 1933

Saamelaismuseo Siidan arkisto (SM, Sámi Museum Siida's archive)

Samii Litton arkisto (SLA, The Archive of Samii Litto)

Annual reports 1950-1953

Documents 1946-1960

Board minutes 1950

Minutes of annual meeting 1953

J. Nuorgam's clipping collection from 1969-1971 (Leikkeet) 
Interviews

Saija Nuorgam (granddaughter of Johan Nuorgam) 12 January 2018

Pertti J. Pelto 22 August 2016

\section{Newspapers}

Sabmelaš 3/1936, 3

Uusi Suomi 21 September 1934

Lapin Kansa 26 July1970; 5 January 1971; 6

August1978

\section{Literature}

Brar-Josan, Novjyot \& Sophie C. Yohani 2019:

"Cultural brokers' role in facilitating informal and formal mental health supports for refugee youth in school and community context: a Canadian case study." British Journal of Guidance \& Counselling 47:4, 512-523.

Clifford, James 1997. "Traveling Cultures". In James Clifford, Routes: Travel and Translation in the Late Twentieth Century. Cambridge: Harvard University Press, 96-116.

Deetz, James \& Patricia Scott Deetz 2000. The Times of Their Lives: Life, Love, and Death in Plymouth Colony. New York: Random House.

Hagedorn, Nancy L. 1988. “'A Friend to go between them': The interpreter as cultural broker during Anglo-Iroquois councils, 1740-70." Ethnohistory 35:1, 60-80.

Hansen, Lars Ivar 1992. “Just K. Qvigstad's contribution to the study of Sami culture." Acta Borealia 2, 47-68.

Hirsti, Reidar 1972. Suenjelfolket - Ved veis ende? Oslo: Tiden.

Hämäläinen, Pekka \& Samuel Truett 2011. "On borderlands." The Journal of American History 98:2, 338-361.

Itkonen, T. I. 1934-1935. "Elämänviisautta Inarin Iijärveltä I-III." Kalevalaseuran vuosikirja 14, 56-67; 15, 77-89; 17, 33-53.

Itkonen, T. I. 1938. "Tunturilappalaisten kansantietoa Inarista." Kalevalaseuran vuosikirja 18, 54-62.
Itkonen, T. I. 1939. "Inarin tunturilappalaisten joikuja." Kalevalaseuran vuosikirja 19, 9-16.

Itkonen, T. I. 1948. Suomen lappalaiset I-II. Helsinki: WSOY.

Itkonen, T. I. 1960. "Johan Nuorgam 60-jahkasaš." Sabmelaš 1-2, 2-3.

Jernsletten, Regnor 1997. "Reindrift, samevenner og samisk etnopolitikk i Norden 1945-1975.” In Bjørn-Petter Finstad, Lars Ivar Hansen, Henry Minde \& Hallvard Tjelmeland (eds.). Stat, religion, etnisitet. Rapport fra Skibotn-konferanse, 1996. Tromsø: Sámedutkamiid guovddaš, 277300.

Karlsson, Christer 1995. "Experternas roll i samepolitiken." Politologen 1, 43-49.

Katsaus 1937. Katsaus Lapin Sivistysseuran 5-vuotiseen toimintaan 1932-1937. Helsinki: Sana.

Kidwell, Clara Sue 1992. "Indian Women as Cultural Mediators." Ethnohistory 39:2, 97-107.

Lantto, Patrik 2000. Tiden börjar på nytt. En analys av samernas etnopolitiska mobilisering $i$ Sverige 1900-1950. Umeå: Umeå universitet.

Lehtola, Veli-Pekka 1997. Saamelaiset - historia, yhteiskunta, taide. Inari: Kustannus-Puntsi.

Lehtola, Veli-Pekka 2003. "Nousun ja tuhon vuodet (1939-1965).” In Veli-Pekka Lehtola (ed.). Inari Aanaar - Inarin historia jääkaudesta nykypäivään. Inari: Inarin kunta, 350-487.

Lehtola, Veli-Pekka 2005a. "Research and activism in Sámi politics: The ideas and achievements of Karl Nickul towards securing governance for the Sámi." Acta Borealia 1, 153-169.

Lehtola, Veli-Pekka 2005b “The Radical Sámi Movement and Establishing of the Sámi Parliament in Finland, 1969-1973." In Peter Sköld \& Per Axelsson (eds.). Igår, idag, imorgon - samerna, politiken och vetenskapen. Umeå: Centrum för samisk forskning, 161-178.

Lehtola, Veli-Pekka 2012. Saamelaiset suomalaiset. Kohtaamisia 1896-1953. Helsinki: SKS.

Lehtola, Veli-Pekka 2017. "Vanishing Lapps, progress in action. Finnish lappology and representations 


\section{JOHAN NUORgAM: SÁmi SQUANTO AND CULTURAL BROKER}

of the Sámi in publicity in the early 20th century." Arctic and North 2, 83-102. DOI:10.17238/ issn2221-2698.2017.27.94.

Lindquist, Johan 2015. "Brokers and Brokerage." International Encyclopedia of Social and Behavioral Science, 2nd edition. Amsterdam: Elsevier.

Michie, Michael. "The role of culture brokers in intercultural science education." Paper presented at the 34th annual conference of the Australasian Science Education Research Association held in Melbourne, 10-12 July 2003. See http://members. ozemail.com.au/\%7Emmichie/culture_brokers1. htm.

Niiranen, Timo 1987. Axel Olai Heikel. Suomalaisen kansatieteen ja arkeologian tutkija. Helsinki: Snellman-instituutti.

Nuorgam, Juhani 1982. Dološ dábit ja vierut Idjajávrri guovlluin. Bajasčálli: Paavo Ravila. Deatnu: Jår'galæd'dji.

Nuorgam, Johan 1984. "Nuoraid searvi ráhkaduvvon Anár Čovčjávrái." Sabmelaš 6, 10.

Olsen, Bjørnar 2000. "Bilder fra fortida. Representasjoner av samisk kultur i samiske museer." Nordisk Museologi 2, 13-30.

Potinkara, Nika 2015. Etnisyyden rakentuminen kahden saamelaismuseon perusnäyttelyissä. Jyväskylä: University of Jyväskylä.

Ravila, Paavo 1934. Reste lappischen Volksglauben. Ges. und hrsg. von Paavo Ravila. Helsinki: Suomalaisugrilainen seura.

Rydving, Håkan 2010. "Samiska överhetspersoner i Sverige-Finland under 1600-talet." In Elsa Mundal and Håkan Rydving (eds.). Samer som "de andra", Samer om "de andra". Identitet och etnicitet i nordiska kulturmöter. Umeå: Umeå universitet, 259-265.

Sainio, Matti A. 1963. "Inarin saamelaismuseo." Kotiseutu 1, 120-123.

"Sámi Čuvgehussearvvi stivra 1932-1984." In Johannes Helander, Matti Mykkänen, Erkki Nickul, Tarmo Salo \& Lasse Sammallahti (eds.). Bálggis. Polku. Sámi Čuvgehussearvvi 1932-1982 Lapin Sivistysseura. Helsinki: Lapin Sivistysseura 1984, 113-115.

Szasz, Margaret Connell 1994a. "Introduction." In Margaret Connell Szasz (eds.). Between Indian and White World. The Cultural Broker. Norman and London: University of Oklahoma Press, 3-20.

Szasz, Margaret Connell 1994b. "Conclusion." In Margaret Connell Szasz (eds.). Between Indian and White World. The Cultural Broker. Norman and London: University of Oklahoma Press, 94-300.

White, Richard 2010/1991. The Middle Ground: Indians, Empires, and Republics in the Great Lakes Region, 1650-1815. Cambridge: Cambridge University Press.

Veli-Pekka Lehtola, Ph.D., Professor of Saami cultural studies

veli-pekka.lehtola@oulu.fi

Giellagas Institute for Saami Studies

University of Oulu

PO Box 1000, 90014 University of Oulu, Finland 